\title{
Economic Evaluation of Rice-Based Cropping Systems under Rainfed Medium Land Situation of Assam
}

\author{
Jayanta Kalita $^{1 *}$, H. C. Bhattacharyya ${ }^{2}$, R. K. Thakuria ${ }^{3}$, \\ D. Bhattacharyya ${ }^{4}$, A. Sarmah ${ }^{5}$ and K. Das ${ }^{6}$ \\ ${ }^{1}$ Agronomy, AAU, ${ }^{2} A A U,{ }^{3}$ AICRP on Water Management, AAU, ${ }^{4}$ Soils, ${ }^{5}$ Agronomy, ${ }^{6}$ Crop \\ Physiology, AAU Jorhat, India \\ *Corresponding author
}

\section{A B S T R A C T}

\begin{tabular}{|l|}
\hline Ke y w o r d s \\
Cropping system, \\
Rice equivalently \\
yield, Production \\
efficiency, \\
Economic \\
efficiency and \\
relative economic \\
efficiency \\
\hline Article Info \\
\hline Accepted: \\
15 March 2020 \\
Available Online: \\
10 April 2020 \\
\hline
\end{tabular}

A field experiment was conducted for two consecutive years during 2015-16 and 2016-17 at farmer's field of Pakorkona village of Kamrup district of Assam to assessed 6 rice-based cropping sequences under rainfed medium land situation for their profitability. The soil of

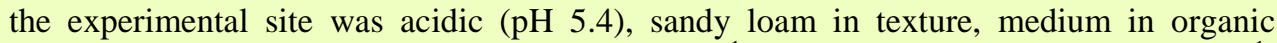
carbon $(0.53 \%)$, low in available $\mathrm{N}\left(263.40 \mathrm{~kg} \mathrm{ha}^{-1}\right)$ and medium in $\mathrm{P}_{2} \mathrm{O}_{5}\left(34.60 \mathrm{~kg} \mathrm{ha}^{-1}\right)$ and $\mathrm{K}_{2} \mathrm{O}\left(152.43 \mathrm{~kg} \mathrm{ha}^{-1}\right)$. The treatments consist of 6 rice based cropping sequences replicated four times in randomized block design viz. rice (Oryza sativa L.) - rapeseed (Brassica camprestis L.) - fellow; rice - rapeseed - blackgram (Vigna mungo L.); ricegarden pea (Pisum sativum. L.)- blackgram; rice - lentil (Lens culinaris Medic) blackgram; rice - garden pea- dhaincha (Sesbania aculeta) and rice - lentil- dhaincha. Economic analysis of the cropping sequences revealed the highest gross return (Rs. $1,38,17 /-\& 1,31, .620 /-\mathrm{ha}^{-1}$ ) and net return (Rs. 69,540/- \& 62,990/- ha $^{-1}$ ) were recorded in rice-g, pea-blackgram sequence but the highest benefit:cost ratio $(2.19 \& 2.12)$ were recorded in rice-g. pea-dhaincha sequence during 2015-16 \& 2016-17 respectively. The economic efficiency was significant with the highest value in rice-g. pea-dhaincha $(243.30$ $\left.\& 228.87 \mathrm{Rs}^{-1} \mathrm{ha}^{-1} \mathrm{day}^{-1}\right)$, followed by rice-g. pea-blackgram sequences $(236.54 \& 214.26$ Rs. $\mathrm{ha}^{-1}$ day $^{-1}$ ) and the highest relative economic efficiency $(170.37 \%$ \& $128.39 \%)$ over predominant rice-rapeseed-fallow sequence were recorded in rice-g. pea-blackgram followed by $151.63 \% \& 120.40 \%$ in rice-g. pea- dhaincha cropping sequence during 2015-16 \& 2016-17 respectivelv.

\section{Introduction}

Agriculture being the main income source for over 70 per cent of the rural population and for small and marginal farmers (85 per cent) in Assam, contributes about 17 per cent of the state domestic product. The predominant cropping systems followed in the state are mainly rice based ones like rice-fallow, ricerice, rice-rapeseed (Toria), jute-rice and rice- vegetables etc. In view of the changing needs of farmers, market demand, state and national priorities, soil degradation and climate change there is a need to diversify the cropping systems especially to increase farmers' income and maintaining soil health.

Rice based cropping systems are widespread in the eastern part of India, which covers around 43 per cent of rice area of the country. 
Rice in north eastern region of India grown in varied ecosystems and the diversification index of rice based cropping system is heavily influenced by rice. Besides, at farmer's level, potential productivity and monetary benefits act as guiding principles while opting for a particular crop/cropping system (Baishya et al., 2016).

In recent years double and triple cropping are more focusing points for increasing farmers income, so diversification and intensification of cropping systems with remunerative and efficient crops like pulses, oilseeds and vegetables has great scope to generate maximum net profit per unit investment per unit time to farmers. So, keeping in view there is a need of identification of a suitable rice based cropping sequence to enhance the system productivity, profitability and cropping intensity of the state.

Diversification and intensification of ricebased systems to increase productivity per unit resource is very pertinent. The diversification of cropping system is necessary to get higher yield and return, to maintain soil health, sustain environment and meet daily requirement of human and animals (Samui et al., 2004).

\section{Materials and Methods}

A field experiment was conducted for two consecutive years during 2015-16 and 201617 at farmer's field of Pakorkona village of Kamrup district of Assam to assessed 6 ricebased cropping sequences under rainfed medium land situation for their productivity, profitability. The soil was acidic ( $\mathrm{pH} 5.4$ ), sandy loam in texture, medium in organic carbon $(0.53 \%)$, low in available $\mathrm{N}$ (263.40 $\left.\mathrm{kg} \mathrm{ha}^{-1}\right)$ and medium in $\mathrm{P}_{2} \mathrm{O}_{5}\left(34.60 \mathrm{~kg} \mathrm{ha}^{-1}\right)$ and $\mathrm{K}_{2} \mathrm{O}\left(152.43 \mathrm{~kg} \mathrm{ha}^{-1}\right)$. The treatments consisted of six rice based cropping sequences replicated four times in randomized block design viz. rice (Oryza sativa L.)- rapeseed (Brassica camprestis L.)-fallow $\left(\mathrm{T}_{1}\right.$ ); rice-rapeseed-blackgram (Vigna mungo L.) $\left(\mathrm{T}_{2}\right)$; rice-garden pea (Pisum sativum. L.)blackgram $\left(\mathrm{T}_{3}\right)$; rice-lentil (Lens culinaris Medic)-blackgram $\left(\mathrm{T}_{4}\right)$; rice-garden peadhaincha (Sesbania aculeta) $\left(\mathrm{T}_{5}\right)$ and ricelentil-dhaincha $\left(\mathrm{T}_{6}\right)$. For comparison between different cropping systems, the yields of all the crops in the sequences were converted into rice equivalent yield (REY). The REY of the systems were calculated in terms of winter rice using the following formula:

$\mathrm{REY}=\Sigma \mathrm{Yi} \times \mathrm{Pi} / \mathrm{P}(\mathrm{p})$

where, $\mathrm{Yi}=$ yield of different crops; $\mathrm{Pi}=$ price of respective crops and $\mathrm{P}(\mathrm{p})=$ price of rice.

Productivity values in terms of $\mathrm{kg} \mathrm{ha}^{-1}$ day $^{-1}$ was calculated by dividing the production of the sequence by 365 days and profitability in terms of Rs. ha ${ }^{-1}$ day $^{-1}$ was obtained by dividing net returns of the sequence by total duration of the sequence (Rautaray, 2005).

The economics and the rice-equivalent yield were computed as per market prices during crop season. The relative economic efficiency (REE) of the system was calculated and expressed in percentage (Samanta, 2015).

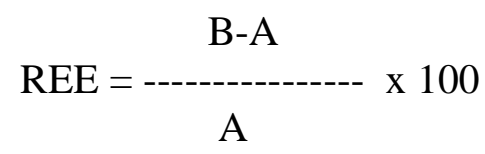

Where,

$A=$ Net return of existing system

$B=$ Net return of diversified cropping system

\section{Results and Discussion}

Rice equivalent yield and production efficiency of different cropping system:

The REY of different rice-based cropping sequences varied widely. The highest REY 
(120.14 \& $\left.114.45 \quad \mathrm{q} \quad \mathrm{ha}^{-1}\right)$, productivity efficiency $\left(40.87 \& 38.93 \mathrm{~kg} \mathrm{ha}^{-1}\right.$ day $^{-1}$ ) were recorded in case of rice-garden pea-blackgram sequence during 2015-16 and 2016-17 respectively (Table 1). Rabi and summer crops mostly influenced these parameters including REY of the systems. Besides, higher production potential of garden pea and better market price of both blackgram and garden pea contributed much for attaining higher REY in this sequence. Legumes are known to offer special advantage regarding stability of the systems because of their legume effect and wider adaptability to diverse conditions (Kumar et al., 2001).

\section{Economics of different cropping systems}

Economic analysis of the cropping sequences reflected the highest gross return (Rs. $1,38,17 /-\& 1,31, .620 /-\mathrm{ha}^{-1}$ ) and net return (Rs. 69,540/- \& 62,990/- ha $^{-1}$ ) in rice-pea- blackgram sequence; but the highest benefit:cost ratio $(2.19 \& 2.12)$ were recorded in rice-pea-dhaincha sequence during 2015$16 \& 2016-17$ respectively (Table 2). The economic efficiency was of the highest value in rice-pea-dhaincha $(243.30 \& 228.87$ Rs. $\mathrm{ha}^{-1}$ day $\left.^{-1}\right)$, followed by rice-pea-blackgram sequences $\left(236.54 \& 214.26\right.$ Rs. ha ${ }^{-1}$ day $^{-1}$ ) and the highest relative economic efficiency $(170.37 \%$ \& $128.39 \%)$ over predominant rice-rapeseed-fallow sequence were recorded in rice-pea-blackgram followed by 151.63 and $120.40 \%$ in rice-pea-dhaincha cropping sequence during 2015-16 \& 2016-17 respectively (Table 3 ). The contribution of high value of garden pea and blackgram and less system duration is quite evident for the highest production efficiency in rice-garden pea-blackgram cropping system. Economic efficiency increases due to inclusion of vegetables in rice based system (Samant, 2015; Kumar et al., 2014).

Table.1 Rice Equivalent Yield (REY) and Production Efficiency (PE) of different cropping systems

\begin{tabular}{|c|c|c|c|c|c|c|}
\hline \multirow{2}{*}{ Cropping systems } & \multicolumn{3}{|c|}{$\operatorname{REY}\left(\mathbf{q} \mathbf{h a}^{-1}\right)$} & \multicolumn{3}{|c|}{ PE $\left(\mathrm{kg} \mathrm{ha}^{-1}\right.$ day $\left.^{-1}\right)$} \\
\hline & 2015-16 & 2016-17 & Pooled mean & 2015-16 & 2016-17 & Pooled mean \\
\hline Rice-Rapeseed-Fallow & $63.45^{\mathrm{e}}$ & $65.16^{\mathrm{d}}$ & $64.30^{\mathrm{d}}$ & $27.71^{\mathrm{c}}$ & $28.46^{\mathrm{b}}$ & $28.08^{\mathrm{b}}$ \\
\hline Rice-Rapeseed-Blackgram & $90.25^{\mathrm{c}}$ & $85.72^{\mathrm{c}}$ & $87.99^{c}$ & $29.89^{b}$ & $28.48^{\mathrm{b}}$ & $29.18^{b}$ \\
\hline Rice-Garden Pea-Blackgram & $120.14^{\mathrm{a}}$ & $114.45^{\mathrm{a}}$ & $117.29^{\mathrm{a}}$ & $40.87^{\mathrm{a}}$ & $38.93^{\mathrm{a}}$ & $39.90^{\mathrm{a}}$ \\
\hline Rice-Lentil-Blackgram & $100.40^{b}$ & $95.38^{b}$ & $97.89^{b}$ & $29.79^{b}$ & $28.31^{\mathrm{b}}$ & $29.05^{b}$ \\
\hline $\begin{array}{l}\text { Rice-Garden Pea- Dhaincha } \\
\text { (GM) }\end{array}$ & $103.56^{b}$ & $100.23^{b}$ & $101.89^{b}$ & $38.93^{\mathrm{a}}$ & $37.69^{\mathrm{a}}$ & $38.31^{\mathrm{a}}$ \\
\hline Rice-Lentil- Dhaincha (GM) & $79.79^{\mathrm{d}}$ & $78.69^{c}$ & $79.24^{c}$ & $25.82^{\mathrm{c}}$ & $25.47^{\mathrm{d}}$ & $25.64^{c}$ \\
\hline S.Ed \pm & 4.09 & 3.91 & 3.98 & 1.65 & 1.39 & 1.34 \\
\hline $\mathrm{CD}(\mathrm{P}=\mathbf{0 . 0 5})$ & 8.71 & 8.33 & 8.47 & 3.51 & 2.96 & 2.85 \\
\hline CV $(\%)$ & 11.94 & 10.23 & 11.64 & 9.32 & 8.44 & 9.23 \\
\hline
\end{tabular}


Table.2 Economics indices of different cropping systems

\begin{tabular}{|c|c|c|c|c|c|c|c|c|c|c|}
\hline \multirow[t]{2}{*}{ Cropping systems } & \multirow{2}{*}{$\begin{array}{c}\text { System gross } \\
\text { cost } \\
\left(10^{3} \text { Rs./ha) }\right.\end{array}$} & \multicolumn{3}{|c|}{$\begin{array}{c}\text { System gross return } \\
\left(10^{3} \mathrm{Rs} . / \mathrm{ha}\right)\end{array}$} & \multicolumn{3}{|c|}{$\begin{array}{l}\text { System net return } \\
\left(10^{3} \mathrm{Rs} . / \mathrm{ha}\right)\end{array}$} & \multicolumn{3}{|c|}{ system B:C ratio } \\
\hline & & 2015-16 & 2016-17 & $\begin{array}{c}\text { Pooled } \\
\text { mean }\end{array}$ & $\begin{array}{c}2015- \\
16\end{array}$ & $\begin{array}{c}2016- \\
17\end{array}$ & $\begin{array}{c}\text { Pooled } \\
\text { mean }\end{array}$ & $\begin{array}{c}2015- \\
16\end{array}$ & $\begin{array}{c}2016- \\
17\end{array}$ & $\begin{array}{l}\text { Pooled } \\
\text { mean }\end{array}$ \\
\hline Rice-Rapeseed-Fallow & 49.98 & $72.97^{\mathrm{e}}$ & $74.83^{\mathrm{f}}$ & $73.90^{f}$ & $25.72^{\mathrm{e}}$ & $27.58^{d}$ & $26.65^{d}$ & $1.54^{\mathrm{e}}$ & $1.59^{\mathrm{e}}$ & $1.56^{\mathrm{d}}$ \\
\hline Rice-Rapeseed-Blackgram & 63.23 & $103.80^{c}$ & $98.58^{d}$ & $101.19^{\mathrm{d}}$ & $40.58^{d}$ & $35.36^{\mathrm{c}}$ & $37.97^{\mathrm{c}}$ & $1.64^{\mathrm{d}}$ & $1.56^{\mathrm{e}}$ & $1.60^{\mathrm{d}}$ \\
\hline Rice-Pea-Blackgram & 68.63 & $138.17^{\mathrm{a}}$ & $131.62^{\mathrm{a}}$ & $134.89^{\mathrm{a}}$ & $69.54^{\mathrm{a}}$ & $62.99^{a}$ & $66.27^{\mathrm{a}}$ & $2.01^{\mathrm{b}}$ & $1.92^{\mathrm{b}}$ & $1.97^{\mathrm{b}}$ \\
\hline Rice-Lentil-Blackgram & 64.13 & $115.47^{\mathrm{b}}$ & $109.69^{c}$ & $112.58^{c}$ & $51.34^{\mathrm{b}}$ & $45.56^{\mathrm{b}}$ & $48.45^{\mathrm{b}}$ & $1.80^{c}$ & $1.71^{\mathrm{d}}$ & $1.76^{\mathrm{c}}$ \\
\hline Rice-Pea- Dhaincha (GM) & 59.40 & $119.09^{b}$ & $115.25^{b}$ & $117.17^{b}$ & $64.82^{a}$ & $60.88^{\mathrm{a}}$ & $62.80^{\mathrm{a}}$ & $2.19^{\mathrm{a}}$ & $2.12^{\mathrm{a}}$ & $2.16^{\mathrm{a}}$ \\
\hline Rice-Lentil- Dhaincha GM) & 54.90 & $91.76^{d}$ & $90.50 \mathrm{e}$ & $91.13^{\mathrm{e}}$ & $41.89^{d}$ & $40.63^{b}$ & $41.26^{\mathrm{c}}$ & $1.84^{\mathrm{c}}$ & $1.82^{c}$ & $1.83^{\mathrm{c}}$ \\
\hline S.Ed \pm & - & 1.99 & 2.25 & 2.08 & 2.23 & 2.55 & 2.18 & 0.04 & 0.03 & 0.06 \\
\hline $\mathrm{CD}(\mathrm{P}=\mathbf{0 . 0 5})$ & - & 4.24 & 4.88 & 4.43 & 4.82 & 5.43 & 4.64 & 0.09 & 0.06 & 0.13 \\
\hline CV $(\%)$ & & 8.43 & 9.21 & 9.89 & 8.58 & 9.34 & 10.21 & 8.21 & 9.34 & 10.98 \\
\hline
\end{tabular}

Table.3 Economic Efficiency (EE) and Relative Economic Efficiency (REE) of different cropping systems

\begin{tabular}{|c|c|c|c|c|c|c|}
\hline \multirow{2}{*}{ Cropping systems } & \multicolumn{3}{|c|}{ EE (Rs. ha ${ }^{-1}$ day $\left.^{-1}\right)$} & \multirow[b]{2}{*}{ 2015-16 } & \multirow{2}{*}{$\begin{array}{c}\text { REE (\%) } \\
2016-17\end{array}$} & \multirow[b]{2}{*}{ Pooled mean } \\
\hline & 2015-16 & 2016-17 & Pooled mean & & & \\
\hline Rice-Rapeseed-Fallow & $112.30^{\mathrm{d}}$ & $120.44^{\mathrm{d}}$ & $116.37^{\mathrm{e}}$ & - & - & - \\
\hline Rice-Rapeseed-Blackgram & $134.35^{\mathrm{c}}$ & $117.07^{\mathrm{d}}$ & $125.71^{\mathrm{d}}$ & 57.78 & 28.21 & 43.00 \\
\hline Rice-Garden Pea-Blackgram & $236.54^{\mathrm{a}}$ & $214.26^{b}$ & $225.40^{b}$ & 170.37 & 128.39 & 149.38 \\
\hline Rice-Lentil-Blackgram & $152.35^{\mathrm{b}}$ & $135.20^{\mathrm{c}}$ & $143.78^{c}$ & 99.61 & 65.18 & 82.40 \\
\hline Rice-Garden Pea- Dhaincha (GM) & $243.30^{\mathrm{a}}$ & $228.87^{\mathrm{a}}$ & $236.09^{\mathrm{a}}$ & 151.63 & 120.40 & 136.02 \\
\hline Rice-Lentil- Dhaincha (GM) & $135.56^{\mathrm{c}}$ & $131.47^{\mathrm{c}}$ & $133.52^{d}$ & 62.87 & 47.32 & 55.10 \\
\hline S.Ed \pm & 7.23 & 4.46 & 3.89 & - & - & - \\
\hline $\mathrm{CD}(\mathrm{P}=0.05)$ & 15.41 & 9.49 & 8.28 & - & - & - \\
\hline $\mathrm{CV}(\%)$ & 13.73 & 12.19 & 13.45 & - & - & - \\
\hline
\end{tabular}


From the present investigation, it can be concluded that, under rainfed condition of Kamrup district of Assam the existing rice based cropping system can effectively be diversified with inclusion of crops like Lentil, Rapeseed and mustard and Garden pea during rabi season along with Blackgram and Sesbania as green manuring crop during summer which were viable systems in productivity and economical point of view. Among all the tested cropping sequences, the rice-garden pea- dhaincha is the ideal ricebased cropping system in respect of profitability under rainfed medium land situation of Assam. Besides monetary benefits, the system can also contributed to building up of soil health.

\section{References}

Baishya, A., Gogoi, B., Hazarika, J., Hazarika, J. P., Bora, A. S., Das, A. K., Bora, M. and Sutradhar, P. (2016). Maximizing system productivity and profitability through crop intensification and diversification with rice (Oryza sativa)-based cropping systems in acid soils of Assam. Indian J. Agron. 61(3):274-280.
Kumar, A.L., Yadav, D. S., Singh, R. M. (2001). Productivity and stability of rice (Oryza sativa) based-cropping systems in eastern Uttar Pradesh. Indian J. Agron. 46(4): 573- 577.

Kumar, P., Singh, F., Singh, A.P. and Singh, M. (2014). Integrated Nutrient Management in Rice-Pea Cropping System for Sustainable Productivity. Int. J. Engg. Res. Technol. 3(4).

Rautaray, S.K. (2005). Effect of mulching on yield and economics of rainfed rice (Oryza sativa)-based cropping sequence in lower Assam. Indian Journal of Agronomy, 50: 13-15.

Samanta T. K. (2015). System Productivity, Profitability, Sustainability and Soil Health as Influenced by Rice-Based Cropping Systems Under Mid Central Table Land Zone of Odisha. Inter. J. Agri. Sci. 7(11): 0975 - 9107.

Samui, R.C., Kundu, A. L., Majumder, D., Mani, P. K. and Sahu, P. K. (2004). Diversification of rice (Orryza sativa) based cropping system in new alluvial zone of West Bengal. Indian J. Agron., 49(2): $71-73$.

\section{How to cite this article:}

Jayanta Kalita, H. C. Bhattacharyya, R. K. Thakuria, D. Bhattacharyya, A. Sarmah and Das, K. 2020. Economic Evaluation of Rice-Based Cropping Systems under Rainfed Medium Land Situation of Assam. Int.J.Curr.Microbiol.App.Sci. 9(04): 1960-1964.

doi: https://doi.org/10.20546/ijcmas.2020.904.233 